\title{
Twenty top papers-the ones that got away and the results of the top six poll
}

\author{
David Payne digital editor
}

The BMJ, London WC1H 9JR, UK

\begin{abstract}
Many thanks to all our readers, authors, friends, and colleagues past and present who nominated their most memorable paper for this article. ${ }^{1}$

Sadly we couldn't include everybody because of the " 20 " theme, but I wanted to mention this nomination by Utah medical librarian Mike Nielson. Mike is great at giving us constructive feedback about the website (he often notices when things aren't working before we do).
\end{abstract}

Mike's nomination is about feedback. After GP Craig Brown's wife died of a secondary brain tumour, he and his family had concerns about her care and decided to complain. At first his children had mixed feelings about this. They feared it would remind them of a bad experience and have no effect. Brown wanted to make a "compassionate complaint" and to avoid projecting his family's grief on to them. The complaint was well received and he and his family hope it will lead to improvements. $^{2}$

I often describe Peter Arnold as one of the first readers in the world to see our weekly print issue online. Peter is based in Australia and is regularly in touch. He nominated three papers. ${ }^{3-5}$

Peter was not alone in nominating more than one paper. We were flattered that some readers openly told us they were struggling to nominate a single paper and mentioned others when they submitted their nomination. There were several "ones that got away." 6-9

Unsurprisingly, Richard Smith had suggestions from his time as editor. Like Jocalyn Clark, ${ }^{1}$ he wanted to highlight papers about death: "Death has been seen as the great enemy by doctors, but this article (and the accompanying articles in the theme issue) was important in recovering the recognition that a good death is one of the most important things in healthcare." After asking what is a good doctor, ${ }^{10}$ he went on to ask what is a good death? ${ }^{11}$

He also submitted a study of general practitioners' reasons for changing prescribing behaviour, ${ }^{12}$ adding: "I couldn't claim that this article has had a big influence, but it's one that I find I return to more than any other. It showed how doctors are human rather than scientific in how they change their practice."

Richard also picked up Muir Gray's "too much medicine" theme ${ }^{1}$ in citing the print issue published while he was editor. ${ }^{13}$ It marked a point he added, "when modern medicine began to over-reach itself."

Finally, he mentioned the polypill which, in his words, is slowly but surely having a global impact, adding: "It's important to realise that there will be many polypills (off patent drugs with different actions combined into one pill) for many conditions." The paper on reducing cardiovascular disease by more than $80 \%$ contributes to the discussion, he concluded..$^{14}$

As part of our 20th online anniversary celebrations we ran a poll that asked readers to nominate which paper The BMJ should be most proud of publishing.

We confined the poll to Web of Science's top six most highly cited papers from the list of 20 articles. The poll ran from 7 to 15 July 2015 and attracted 576 votes across 55 countries.

Altman's editorial on poor medical research was the clear winner, attracting 252 votes, almost $44 \%$ of the total votes. ${ }^{15}$

A study on knowledge management in primary care came second (89 votes; $15.45 \%$ of total). ${ }^{16}$

Establishing a standard definition for child overweight and obesity came third $(69 ; 11.98 \%) .{ }^{17}$

Multiple imputation for missing data in epidemiological and clinical research came fourth $(61 ; 10.59 \%){ }^{18}$

A trial of zinc supplementation for diarrhoea in Bangladeshi children came fifth $(57 ; 9.9 \%) .{ }^{19}$

A qualitative study of what worries parents when their preschool children are acutely ill came sixth $(48 ; 8.33 \%){ }^{20}$

Many thanks to all those who voted and to readers who responded to the article with other papers that they think have had a major impact.

Competing interests: None declared. 
1 Payne D. Twenty top papers to mark The BMJ's two digital decades. BMJ 2015;351:h3660. (6 July.)

2 Brown C. A compassionate complaint about hospital care made a difference. $B M J$ 2015;350:g7823.

3 Groves T. Managing UK research data for future use. BMJ 2009;338:b1252.

4 Sokol DK. How to treat a Pirahã: medical ethics and cultural difference. BMJ 2015;350:h850.

5 McCartney M, Goldacre B, Chalmers I. Why the GMC should set up a central registry of doctors' competing interests. BMJ 2014;348:g236.

6 Hippisley-Cox J, Coupland C, Vinogradova Y, et al. Derivation and validation of QRISK, a new cardiovascular disease risk score for the United Kingdom: prospective open cohort study. BMJ 2007;335:136.

7 The A-M, Hak T, Koëter G, et al. Collusion in doctor-patient communication about imminent death: an ethnographic study. BMJ 2000;321:1376.

8 Garattini S, Bertele V, Li Bassi L. How can research ethics committees protect patients better? BMJ 2003;326:1199.

9 Greenhalgh T. How to read a paper: getting your bearings (deciding what the paper is about). BMJ 1997;315:243.

10 Hurwitz B, Vass A. What is a good doctor, and how can you make one? BMJ 2002;325:667

11 Smith R. A good death. BMJ 2000;320:129.
12 Armstrong $\mathrm{D}$, Reyburn $\mathrm{H}$, Jones $\mathrm{R}$. A study of general practitioners' reasons for changing their prescribing behaviour. BMJ 1996;312:949.

13 Moynihan R, Smith R. Too much medicine? BMJ 2002;324:859

14 Wald NJ, Law MR. A strategy to reduce cardiovascular disease by more than $80 \%$. BMJ 2003;326:1419.

15 Altman DG. The scandal of poor medical research. BMJ 1994;308:283.

16 Gabbay J, Le May A. Evidence based guidelines or collectively constructed "mindlines?" Ethnographic study of knowledge management in primary care. BMJ 2004:329:1013.

17 Cole TJ, Bellizzi MC, Flegal KM, et al. Establishing a standard definition for child overweight and obesity worldwide: international survey. BMJ 2000;320:1240.

18 Sterne JAC, White IR, Carlin JB. Multiple imputation for missing data in epidemiological and clinical research: potential and pitfalls. BMJ 2009;338:b2393.

19 Baqui AH, Black RE, El Arifeen S, et al. Effect of zinc supplementation started during diarrhoea on morbidity and mortality in Bangladeshi children: community randomised trial. BMJ 2002;325:1059.

20 Kai J. What worries parents when their preschool children are acutely ill, and why: a qualitative study. BMJ 1996;313:983.

Cite this as: BMJ 2015;351:h4125

(c) BMJ Publishing Group Ltd 2015 